\title{
Central Propaganda Figures of Crowds: Citizen, Militant, Worker
}

\author{
Oprea-Valentin Buşu \\ University of Bucharest, Bulevardul Regina Elisabeta 4-12, Bucharest 030018, Romania \\ E-mail address: valentino_busu@yahoo.ro
}

\begin{abstract}
The study explores vagueness area of the crowd concept and points the identification of nodal points. By means of some descriptive, comparative and meta-analytical methods are examining crowds abstract idea limits and are found meaningful convergent paths. It is ascertained that the crowd is not an uniform ideaful construction homogeneous and centripetal, but a multi-layered and multistructured, heterogeneous and centrifuge. The released conclusion is that, despite the disorder within the concept of crowd, inside of it can delineated three fixed stars, three symbolic meaningful figures of crowds: the citizen, the militant and the worker.
\end{abstract}

Keywords: power; political power; social competence; communication

\section{INTRODUCTION}

Among the privileged witnesses of this century, Elias Canetti (1984) was concerned exactly of general relations of the power and the the crowds. He identifies, for crowds, four features, which are correlative to the environmental conditions (Canetti, 1984):

- the crowd always tends to increase; its destiny is to absorb, like a snowball that rolls down on the hill of History, a growing number of individuals;

- free of any formal social relationship, having no hierarchy, the crowd tends to establish within it the absolute equality, as it would aspires to homogeneity of undifferentiation;

- it aims the "density", its goal being to occupy a compact volume, to cover physical distances, separations and voids, its development tending asymptotically to fullness;

- the crowd requires existence of an able common direction to mobilize all its members, thus emphasizing the functional equality. This common direction, that define the roles quasiinevitable of "leaders", allows it to subsist without to disintegrate it.

Power is not emanated by the crowds, but it represents a condition of its subsistence (Rouquette, 2002, p. 20; Borowski, 2013a). When we are examining a particular crowd, each of these features is more or less pronounced. Each of them finds a different echo within the corresponding ideology: either the importance of the leader, or the affirmation of equality, for example, can be emphasized. But these modulations of the identity subjects intensity have no different result than customizing of some examples, adapting of a conjecture: they do not compromise the overall validity of the description. The crowd is emerging thus as a being that 
possesses own characteristics. It defines a framework for the individual psychologies of the interaction, as well the history guides, embeds and determines personal destiny. If we refer to the its externality, we can define the crowd as the number and the concentration in compressed duration of a simultaneity. Communication and consumption occur later, naturally, to confirm the conditions that created them. The crowd and the community are social structures. The crowd difere from community: crowd have not a cousciousness. Andrzej Borowski shows that community is "a sociological category" an dis based on a "mutual commitment" (Borowski, 2014, p. 1).

Suppose that every thing in the world is transposed into image, given to look and fixed at the same time. It's a trend that we can see from the universal spread of photography and electronic means. The fact that certain products are also distributed, consistently shared, simulation and the representation gain more truthfulness than their model; at least is substituted it as developers of the real reality (Vlăduţescu, 2013a; Vlăduţescu, 2014a).

The absolute power is that held by one man, who exercise the dominion over certain subjects. He has, of course, fads and, therefore, favorites: both of them are reflections of desire. He also needs a device that would transmit along his will, thus requires clarks. But, whatver it would be the hardness of this device, it is applied to some individuals recognized as such; in fact, they are concerned only with cases and from this comes imperfections, inertia, tolerances and its omissions (Borowski, 2013bf). The tyrant knows only the crowds of manipulation, used on construction sites or during the war. The rest has to do with people, after all less numerous, and productive ghost that almost can not perceive them. Naturally the crowds can irritate him sometimes, like a sudden storm that breaks a country party. But he did not take them at all seriously and he receive answer, perhaps in the same manner (Vlăduţescu, 2006; Smarandache \& Vlăduţescu, 2014).

What is clear, first of all, is that totalitarian powers use, organize the crowds. But not as they would find them and they would be somewhat forced to manage them. The link between them is original. It is a double implication: totalitarianism can not be achieved without the crowds and the crowd, to be governed, suppose the existence of totalitarianism.

The fact thet the totalitarianism involves that the crowds is an evidence, because the total control means the control of all in all respects and, therefore, the alignment at least normalization, which is not possible without concentration. Not even that the crowd implies totalitarianism is no less obvious: the political existence of the crowd as electorate or "producer" impose its political organization, i.e., its capture and control (Emerson, 2014).

Since the crowd to produce legitimacy, it must scrupulously codified, its conditions of installing and exercising should be set that further, in this framework, can take plase the seduction or the coercion. Thus, the totalitarianism and the crowds there are in a relation of destiny, if we accept that the fate is what happens inevitably.

\section{THREE FIGURES OF CROWDS}

To say that the crowds are composed of individuals is a descriptive truism, but a comprehensive paradox. Figures of crowds are the voices ,in the crowd” (Sutherlin, 2013). In the irreducible singularity, the individual as such is not a constitutive element of the crowd. He does not get this role than from the moment it is absorbed in a general functional category we might call a "figure", in which the specimens are interchangeble, because the behaviors and values of which depend on enter in the same generic models. These are independent of the individual volition: they are not the subject of a choice, because they seem inevitable, and 
"natural", assigned or effects of the human condition; they are not the subject of a choice and because their adoption is exactly the guarantee of the social belonging: how might deploy the life without them? On the one hand the need, which limits the imagination, and on the other hand the recognition comfort of the affiliation, that we want all of us: nothing can be more restrictive (Vlăduţescu \& Ciupercă, 2013). The identity, be it claimed as a personal good, it is only the effect of a program: exactly that one that adjusts the legacy that comes us or the one that requires it, at theater, the play order and the arrangement decided by the director. The three figures that compound the crowds are the Citizen, Militant and Worker. Through a kind of political sublimation, the crowd hero joins these figures.

\section{THE CITIZEN}

It's about the individual whose defining quality, in the eyes of power, is to be active or passive member of society (Milca, 2001; Milca, 2005). This is therefore equalizers category by excellence: rich and poor, scholar and illiterate, peasant and city dweller, the deputy and the taxpayer represents equally a citizen. In addition to this abstract requirement, the personal singularities seem unpredictable data, and the differentiating groups is considered a simple effect of surface that does not compromise the common fund (Măgureanu, 1997; Măgureanu, 2003; Mangra, Cotoc \& Traistaru, 2013). The fact that the concept of citizen is denoted to be more pronounced normative than descriptive is proved by the ideological discourse of the state, which periodically consolidates the belief in the existence of a model of the "good" citizen: the one who makes his "duty", thus demonstrating the "responsibility", who is involved, denounces, is informed and is conformed; in a word, one that adheres to values that are offered and who listens the lessons that are given. He assumes roles which are acquired on a stage that is offered; he is "informed" in the traditional way of descendent communication and is mobilized or quiet through propaganda; his concept is not the result of an induction that starts from the observation of some real components, but the projection of ideological and practical necessity.

Must to recognize: the citizen " thinker " is often incompetent. Numerous surveys show that most voters in developed countries only have low political knowledge, both in terms of institutions and stakes or actors. Their decisions are often motivated by impressions and emotions, by impulse and emotion than analysis. To mention also what we know from Lazarsfeld, Berelson and Gaudet (1948): The voters' option is directly determined by the influence of their relatives, exerted during informal conversations that allow adaptation and supporting of the arguments, without any change, in the most of part of time, of each thinks, hopes and feels (Siminică \& Traistaru, 2013). Thus, the ideas are not separated from interpersonal relations, to whose consolidation the shared opinion can concur: we assist to the dynamics of a sentiment within the conservative dynamics of a network of interactions.

\section{THE MILITANT}

It is closely related, not only by etymology, with the mobilized soldier. Because of his knowledge of land and doctrine, he has the role of scout, and even "avant-garde" of crowds. He has the duty to point the way and, if necessary, to open the way. But he also serves the corrective function, sometimes repressive of the escorts. Whether or accompanies or guides, if punishes or educates, his states of mind and his peculiarities have little importance. His 
cardinal virtue is loyalty, which translates through obedience anyway (Dima \& Vlăduţescu, 2012; Powell, 2014).

There is not militant faithless and party apparatus. In the absence of first, his conduct would not make sense in his own eyes, in the absence of the second, would be helpless and would come to have doubts. Propagandist and bureaucrat, the militant organizes the crowd from which is coming to direct it towards goals which he shares at his turn. To believe means to a certainly to be also practitioner, and the formula is reversing. The militant is the possessor of an instrumental truth which exceeds and makes him to overcome the others, because he believes that he serves them, he uses them or he makes them to serve. In fact he oscillates between dedication and contempt (Măgureanu, 2006).

However, it will say us, the militant committed at a time, joined a group explicitly and, in this respect he was bounded by others, though he was not required to do it. This destiny is therefore not quite so common. Actually individual trajectories of adherence are multiple and unpredictable. There are very few specific regularities in the psychological variables proper level, so that the biographical method, by clinic definition, may seems more appropriate to approach of the understanding of an engagement and its evolution (Frigioiu, 2010; Borowski, 2013c).

Sociological analysis should incline to reveal rather the regulators trends of the constraints circumstances. Knowing who will take a certain role and why this role will be busy anyway are two completely different things; the first refers to an unlimited number of circumstances and accidents (personality traits, characteristics of family constellation, the chance encounters and influences, development of interpersonal relationships, etc.), while, the second is pointing structures and embedded conditions, especially collective ideological elaborations. Obviously, considering the general is more rigorous than the particular examining, and to study a genetic class is more relevant than examining a specimen. The "Figure" is the lowest common denominator of those who embody, and nor their precipitant of the particularities; it should be conceived first of all as a structure of roles.

\section{THE WORKER}

Defined by what is producing what wins, what buys and what it costs. By expanding and his manifest necessity, the Worker is in our time the most prominent of the three. The Consumer, who advertising reflects and creates, is his the latest version; he gives them all a common identity which constitute the crowd as a kind of objective evidence with economic base. The knowing of the crowds psychology constitutes the basis of the state human who doesn't want to control - thing which become today difficult but at least to not get totally dominated by them. The crowd psychology shows that laws and institutions exert a weak influence on their impulsive nature and the crowds are unable to have other opinions than those that have been suggested. The rules arising from pure theoretical equity could not direct them. Only impressions embedded in their soul can seduce (Le Bon, 2007, p. 6).

Regularly, through crowds we understand the bringing together of individuals, regardless of nationality, profession or their sex and the chance that they may be together. It is not easy to describe the spirit of the crowds, its configuration varying not only by race and the composition of communities, but also to the nature and intensity of the received stimuli (Frigioiu, 2008; Măgureanu, 2006) . 
The most striking feature of a psychological crowd is that, regardless of the individuals composing it, regardless of similarities or differences in their way of living, the occupations, the characters or their level of intelligence, the only fact that people are transformed into a crowd invest them with a kind of collective soul. It makes them to feel, to think and to act in a manner totally different from that in which they would feel and would think and would act each of the individuals composing the crowd, taken isolated. Some ideas, some feelings does not appear and does not materialize by acts only in individuals who constitutes a crowd.

The "psychological" crowd is a temporary "being", composed of heterogeneous elements, but welded for a while, like the cells of a living organism, which in their totality establish a new being, having different features of each of the component cells.

The crowds can be easily pushed to leave killed for the triumph of faith or of an idea, can be passionate for glory or honor, can be trained, almost without bread and weapons, as crusades during the crusades, to release from the hands of unbelievers the Holy Sepulcher or to defend the homeland. Heroism, of course, less unconsciously, but with such a heroism was written the history. If we would not move to nations asset than large lucid action, the annals of the world would be much poorer.

\section{CONCLUSION}

More specific features of the crowds, as impulsiveness, irritability, inability to reason, lack of discernment and critical spirit, the exaggeration of feelings and others, are observed to the beings belonging to some inferior forms of evolution, as primitive peoples and children. The various impulses to which that respond crowds can be generous or cruel, heroic or cowardice marked, but they will always be in so compelling, that even the spirit of conservation goes before them. Given being the variety of susceptible stimuli of suggestion on the crowds and that they always respond to them, results that the crowds are extremely mobile. In a split of second, they can move from the bloodiest ferocity to the generosity or to absolute heroism. The crowds easily become executioners and, not more easily, martyrs.

\section{References}

[1] Andrzej Borowski (a), International Letters of Social and Humanistic Sciences 11 (2014) $1-168$.

[2] G. Sutherlin. Journal of information science 39(3) (2013) 397-409.

[3] G. Le Bon (2007). Psihologia mulţimilor. Editura Antet.

[4] Donovan A. McFarlane, International Letters of Social and Humanistic Sciences 4 (2013) $35-44$.

[5] Maria Nowicka-Scowron; Ioan Constantin Dima; Ştefan Vlăduţescu. International Journal of Management Sciences and Business Research 1(8) (2012) 27-35.

[6] Andrzej Borowski (b), International Letters of Social and Humanistic Sciences 2 (2014) 110-121. 
[7] Ştefan Vlăduţescu (2006). Comunicare jurnalistică negativă. Bucureşti: Editura Academiei.

[8] Gheorghe Teodorescu (2000). Putere, autoritate şi comunicare politică. Bucureşti: Nemira.

[9] Andrzej Borowski (c), International Letters of Social and Humanistic Sciences 3 (2013) 69-74.

[10] Ştefan Vlăduţescu, International Letters of Social and Humanistic Sciences 10(2) (2014) 100-106.

[11] N. Gueguen (2007). Psihologia manipulării şi a supunerii. Iaşi: Editura Polirom.

[12] Ştefan Vlăduţescu; Ella Magdalena Ciupercă (2013). Next Flood Level of Communication: Social Networks. Aachen: Shaker Verlag.

[13] M.-L. Rouquette (2002). Despre cunoaşterea maselor. Eseu de psihologie politicã. Iaşi: Editura Polirom.

[14] Virgil Măgureanu (2003). Declinul sau apoteoza puterii? RAO.

[15] Ştefan Vlăduţescu (2013). Three Diachronic Paradigms of Communication. International.

[16] J. Tittenbrun, International Letters of Social and Humanistic Sciences 2 (2014) 20-40.

[17] Ioan Constantin Dima; Ştefan Vlăduţescu (2012). Persuasion elements used in logistical negotiation: Persuasive logistical negotiation. Saarbrucken: LAP Lambert Academic Publishing.

[18] M. G. Mangra; E. A. Cotoc; A. Traistaru (2013). Sustainable Economic Development Through Environmental Management Systems Implementation. Journal.

[19] Andrzej Borowski (d), International Letters of Social and Humanistic Sciences 4 (2013) 70-74.

[20] Ella Magdalena Ciupercă; Ştefan Vlăduţescu (2010). Securitatea naţională şi manipularea opiniei publice. Bucureşti: Editura Didactică şi Pedagogică.

[21] Virgil Măgureanu (2006). Sociologie politică. RAO.

[22] Florentin Smarandache; Ştefan Vlăduţescu (2014). Neutrosophic Emergences and Incidences in Communication and Information. Saarbrucken: LAP Lambert Academic Publishing.

[23] N. Frigioiu (2010). Puterea imaginii şi imaginarul Puterii. Bucureşti: Editura Economică.

[24] V. Măgureanu (1997). Studii de sociologie politică. Bucureşti: Editura Albatros.

[25] V. Măgureanu (2006). Sociologie politică. Bucureşti: Editura Rao.

[26] Ştefan Vlăduţescu, International Letters of Social and Humanistic Sciences 7 (2014) 8-13.

[27] Marian Siminică; Aurelia Traistaru (2013). Self-Directed Learning in Economic Education. International. 
[28] M. Milca (2001). Geneza teoriei elitelor. Provocarea neomachiavellienilor. Bucureşti: Editura Economică.

[29] Ştefan Vlăduţescu (2013a). A Completion to the Traditions Matrix-Standard - R. T. Craig, Induced by the Transformation of Communication-as-a-Field Membrane in Communication-as-a-Universe Membrane. American International.

[30] Mihaela Gabriela Paun (2013). Changes in Management as an Instrument of Educational Intervention. European.

[31] Ştefan Vlăduţescu (2013b). The Communication Membranes. European .

[32] Cristina Pretorian; Dan Ionescu, International Letters of Social and Humanistic Sciences 9 (2014) 49-56.

[33] V. Măgureanu (2003). Declinul sau apoteoza puterii. Bucureşti: Editura Rao.

[34] Ştefan Vlăduţescu (2013c). Principle of the Irrepressible Emergence of the Message. Jokull.

[35] K. Dowding (1998). Puterea. Bucureşti: Editura Du Style.

[36] V. Măgureanu (2009). De la regimul comunist la regimul Iliescu. Bucureşti: Editura Rao.

[37] Ştefan Vlăduţescu (2014). Eight computational-communicative operations of building information. Mitteilungen Klosterneuburg.

[38] I. Bădescu (2011). Sociologie rurală. Bucureşti: Mica Valahie.

[39] Costel Florescu (2007). Puterea personală, poziţiei, organizaţiei. Bucureşti: Editura Universitară.

[40] Nicolae Frigioiu (2004). Imaginea publică a liderilor şi instituţiilor politice. Bucureşti: Comunicare.ro

[41] Ştefan Vlăduţescu (2013). What Kind of Communication Is Philosophy. Jokull.

[42] N. Frigioiu (2008). Imaginea publică a liderilor şi instituţiilor. Bucureşti: Editura Comunicare.ro

[43] Ştefan Vlăduţescu (2013). Message as Fundamental Discursive Commitment of Communication. Journal.

[44] Victor Duţă (2006). Puterea fără limite. Bucureşti: Editura Ştefan.

[45] M. Weber (1992). Politica, o vocaţie şi o profesie. Bucureşti: Editura Anima.

[46] Ştefan Vlăduțescu, Journal of Studies in Social Sciences 5(2) (2013) 276-287.

[47] Ioan Constantin Dima; Janusz Grabara; Ştefan Vlăduţescu. Journal on Business Review 2(2) (2012) 4.

[48] M. Milca (2005). Identitate românească şi europeană. Bucureşti: Editura Agir.

[49] Jason L. Powell, International Letters of Social and Humanistic Sciences 7 (2014) 22-30. 
[50] A. Borowski (e), International Letters of Social and Humanistic Sciences 6 (2013) 86-90.

[51] Andrzej Borowski (f), International Letters of Social and Humanistic Sciences 2 (2013) 56-60.

[52] Peter Emerson, International Letters of Social and Humanistic Sciences 10(2) (2014) 132-155.

( Received 18 February 2014; accepted 24 February 2014 ) 